\title{
Religion, Modernity, and the Nation: Postscripts of Malabar Migration
}

\author{
Ambili Anna Markose \\ Ph.D Candidate, Centre for Comparative Literature, University of Hydrebad. \\ Email: ambilianna@gmail.com
}

Received July 30, 2017; Revised September 01, 2017; Accepted September 18, 2017; Published September $20,2017$.

\begin{abstract}
This paper attempts to read the event of Malabar migration as articulated in the migrant writings. Arguably, the event and the representations - both individual and community narratives - are political documents which facilitate different discourses on minority politics in Kerala/India. Community identity and claims of legitimacy in a secular modern state become crucial in these narratives which make them significant within the sphere of history-literature on the historical event of Malabar migration. The narratives are examined in view of the cultural and political signification of Syrian Christian community and the very act of writing history has in the ideological nexus associated within. In doing so, the paper looks at the way these discourses make inroads to the idea of modernity, nation-state, and thereby opens up discursive terrains of the politics of representation and the articulations of the self.
\end{abstract}

Keywords: Migration, Syrian Christians, Modernity, Minority, Nation.

\section{Introduction}

The Malayalam speaking community in the southern part of India has been recognized as a highly mobile, migration-prone, group of people. Migration, generally, refers to movement of peoples from their places of domicile to regions outside their political sovereign nation-state. However, migration can also denote "exodus within the borders" (Korn, 200o). In contrast to the international migration patterns, my focus is on the historical and cultural contexts of a specific migration within the borders of a single state of Kerala. My subject of study is the massive peasant and agrarian migration from the princely state of Travancore (or Thiruvithamcoor) to Malabar, ${ }^{1}$ which was part of the Madras Presidency under colonial domination, with high concentration between 1920 and 1970. In this case the movement was from one region to another geographically close region. Both regions had different governmental systems; they, however, had a common language, with dialectal variations and, by and large, had similar cultures and communities. This migration started during the 1920 s when the political sovereign India existed only as a concept put forward by the nationalist movement of the time. Hence, to the migrants, the state formation in 1956 meant the unification of their place of origin and their place of destination into one political and territorial unit under one nation-state (Joseph, 2005, P. 125).

Narratives are integral to any identity/community articulation in view of the fact that they provide a platform for these identities to be manifested in different forms in the public sphere. The identity formation of the Syrian Christians is narrativized in a particular fashion by both the people inside the migrant community and outside. These narratives assume significance in

(c) AesthetixMS 2016. This Open Access article is published under a Creative Commons Attribution Non-Commercial 4.0 International License (http://creativecommons.org/licenses/by-nc/4.0/), which permits non-commercial re-use, distribution, and reproduction in any medium, provided the original work is properly cited. For citation use the DOI. For commercial re-use, please contact editor@rupkatha.com. 
discussions of a larger Christian identity, and in terms of specific communities and castes, as mapped against a "national" identity. The narratives regarding migration emerge as the major site where the Syrian Christian identity is articulated in a very specific and novel manner in the history-literature on Christianity. In order to illustrate this, I read different kinds of texts which include literary works and those published by the Church or Church-related institutions. Such a reading, hopefully, would facilitate a more comprehensive understanding of the Syrian Christian migrant self from different perspectives and ideological streams. This analysis of community narratives becomes pertinent to understand about the ways in which minority identities are structured inside the modern nation state in India.

\section{Christianity, Modernity and the event of Migration}

The majority of migrants during the process of migration belonged to Christian community, especially the Syrian Christian or the Saint Thomas Christian community, which is considered to be one of the oldest Churches in India. The popular belief about the origin of Syrian Christians is the one related to the arrival of St. Thomas, the disciple of Jesus Christ at Kodungallore, which, allegedly, led to conversion of local Namboodiri ${ }^{2}$ families to Christianity. The tale, invariably, is used to attest the community claims of "upper" caste origin. Nevertheless, there is no unambiguous and substantial evidential basis to prove the "upper" caste lineage of the Syrian Christians of Kerala. Notwithstanding the evasiveness of the origin myths, Syrian Christians had been enjoying a privileged position in the public sphere of the state, and they remained outside the fold of the caste structure, thus escaping social discriminations. It is crucial to note that Travancore had many Syrian Christians in its Government and political structure, albeit these representations were limited to a particular class of people who were very few in numbers. To give an important example: the first non-Hindu Minister of Travancore, Thachil Matthoo Tharakan was a Syrian Christian. Seemingly the "othering" of the Syrian Christians could be religion based than based on caste.

In short, in the context of Indian Christianity, the emergence of Christian institutions in India took place long before the arrival of Europeans and long before the British Raj (Frykenberg, 2003, p. 9). In this discussion, it is important to note that the history of the Syrian Christians of Kerala is not related to the establishment of Western political power or the coming of Western missionaries in India. It is with the advent of religious nationalism that the Indian Christians were seen as a homogenous entity different from the so-called "national community." By then Christianity had almost been labeled as the religion of the colonial power. On the other hand, many Christian movements in nineteenth and twentieth century South India worked towards forming a distinct Christian identity. It is observed that just before and after the turn of the twentieth century, the Catholics of Madras Presidency were marked by a growing self consciousness and a new sense of public commitment which is expressed through an evolving Catholic press. This project was to defend Catholic interests amid the signs of a rising Hindu Nationalism (Mallampally, 2004, P. 89). This can also be viewed as a kind of institutional attempt to resist Indian modernity and to evolve its own identity.

Christian community was seen as antagonistic to the native tradition since it was imagined essentially as a colonial religion during the nationalist movement. This imagination was prevalent within the community also, though not widely accepted by the religious leaders. The imagined patronage to colonial authority is not in the form of direct interference in the affairs of the Church, but by making the Church of Malabar, a part of Pan-Indian Christianity. It has been argued that: 
"Nationalist rhetoric, however continually exaggerated the actual extent to which "panChristian" networks shaped the attitudes and commitments held among Indian Christians. The Christian identity extolled by these networks often stood at odds with the actual consciousness of Christians within Indian Society (Mallampally, 2004, P. 87).”

This pan-Christian identity is a homogenous entity as conceived by the proponents of a "universal Christianity." As a result of an essentialist aspiration for an ideal pan-Indian Christianity, the Church started to symbolize an alternate national identity. Mallampally observes:

"Within the climate of Indian nationalism, an allegiance to the Pope or to the Anglican establishment, or membership in the YMCA, suggested an alternative national identity that stood at odds with a generally "Indian" one-a perception that Indian Catholics and Protestants took great pains to refute (Mallampally, 2004, P. 87)."

This signifies the predicament of the Church, as a community of individuals who has access to different spheres of colonial modernity. This alternative identity is against the project of anticolonial nationalism which operates by dividing the world of social institutions and practices into two domains: the material and the spiritual (Chatterjee, 1993, P. 6). Undoubtedly, this ambiguous identity of Christians made inroads into the dominant discourses on migration at large. Moreover, the period is also significant because of the emergence of a religious Hindu nationalism as part of the nationalist movement, which was generally moving towards the idea of a homogenous national community. Apparently, this idea of a nation was propounded by the Indian nationalist movement to facilitate a political unification through a nationalization movement, which was primarily based on the rhetoric of tradition-modernity discourse. Indian National Congress succeeded in creating this by promoting a religious nationalism which is hegemonic in nature. This hegemonic religious nationalism established itself with the help of a selective use of the discourses of modernity which also served as the main project of anti-colonial nationalism.

Arguably, the shifts in personal identity and selfhood, in turn, influence the construction of a past (Gardner, 2002, P. 86). By implication, the way in which one makes sense of the past is foundational to one's idea of present. The establishment of problematic binaries in the anticolonial nationalism makes it clear that the ways in which these "upper" caste converts and "lower" caste converts relate to the idea of nationalism are based on the premise of caste politics. So, nation remained as nostalgia for the "upper" caste converts like that of "upper" caste Hindus. Apparently, the "lower" caste Christians were driven out of this imagination of "nation as nostalgia" because "their spiritual journey began in a critique of Hinduism" (Pandian, 2003, P. 5363). As Pandian (2003) rightly puts it: "Nationalism asserts itself not merely by constructing external others, but also by means of producing internal others" (P. 5357).

The colonial rule acknowledged the native elites as the legitimate representatives of the nation and the private sphere became an arena of the dominant discourse (Ali, 2001, P. 2419). In the post colonial state, Christians were denied entry into the private/spiritual sphere for not including in the group of legitimate representatives mainly because they possess a religion which "seems" opposed to the "national community." This is equal to a denial of existence in the public sphere. Hence, they had to articulate a new sense of subjectivity in order to enter into the mainstream of the society. Seemingly, Syrian Christians' engagement with the idea of nation is also in terms of their assertive religious identity, the articulation of which is dependent on the transformation of civil society in colonial and post-colonial regimes. Community identities have been highly influential in the social and economic mobilization in the post-colonial state and hence this attempt to be in the mainstream has wider implications for a national minority. 
To recapitulate, as stated already, the stereotype of Christianity as essentially a Western religion is derived from the complexity of Indian Church history, which has both Eastern and Western legacies to claim, owing to the schisms and conversions histories of Indian Church over time. In some sense, Christianity also provided a complete justification for the imperial mission which made the religion of Christianity a colonial ideology that need to be resisted. Precisely, the institutional affiliations of Christian communities to structures outside the geography of India and its label as a colonial religion gave Christianity an alternative signification against nationalism, necessitating assertive religious identities. The same problem of identity was also translated to the region of Malabar where the Syrian Christians were seen as antagonistic to the culture of the region. In this regard, I examine many migrant narratives as a response to this animosity in the cultural sphere.

Migration started before the linguistically and geographically defined reorganization of Indian states. In spite of the similarities of topographical conditions, Malabar had altogether a different pattern of agriculture development and land-individual relationship (Joseph, 2005, P. 120). The political scenario obviously and inevitably stood at odds with that of Travancore, as Malabar was under British rule. Malabar had a relatively smaller number of Christians among its population and most of them belonged to either Latin Catholic or other communities. They had a minimal influence in the public sphere of the region. Migration introduced Syrian Christians as a new community in Malabar. It seems that in Malabar they did not have any privilege; in fact, they were seen as antagonistic to the culture and society of Malabar. Most of the land in Malabar was under the control of upper caste Hindu landlords who had a very pronounced caste consciousness. Hence, Syrian Christians had to struggle for recognition in Malabar and their recognition as migrants to Malabar is community-specific and caste-specific.

Creation of networks of their own is one of the normative methods adopted by any class of migrants to ensure their security and maintain their identity in alien spaces. Church played a crucial role in the construction of the community throughout migration as these migrant Christians made it possible through the establishment of parishes wherever they went. That is why it is said that Christian migrants do not simply carry their religions to unknown places but they bring their religious leaders wherever they go (Williams, 2000, P. 29). The religious leaders, most often priests, in effect came to function as political leaders for these migrant Christians, drawing similar lines of thought where Gandhi was a political representative for the British and a Hindu Sanyasi for the Hindus (Kaviraj, 2003, P. 147).

On the one hand, as a religious community, Christians had to turn to the colonial power for a spiritual patronage. On the other hand, as Indians, they were forced to be part of the national movement which was antagonistic to the Christian (British) power. So a greater part of the community chose to remain indifferent and outside the currents of nationalism (Nair, 1981, P. 286). Another group of Syrian Christians embraced the advent of modernity by removing the symbols of mainstream Hinduism which is basically Brahminical. But, by doing so, they were isolating themselves from the currents of the emerging religious nationalism, i.e., Hindu Nationalism. By alienating themselves from this idea of nation, in fact, they negate their privileged position in the social structure. So they had to be part of the national community without sacrificing their religiosity.

Hence this paper looks at migration, community assertions, and identity constructions of Syrian Christians as sites where the ideology of a hegemonic society is operated. It seems that these Christians, who had been suffering due to the hostile political milieu in Travancore which favored Hindus and showed inclinations of a theocratic rule, were in fact moving towards a 
religious nation where their existence is more problematic. Their entry into politics and identity articulations in the independent state must be analyzed within the premise of these currents of modernity, nationalism, and legitimacy. Malabar migration turns out to be a site where these issues become fundamental in the process of an upward mobilization in society.

\section{Narration, History, and the Self}

It has been observed that, migration to Malabar is a part of a developmental discourse in the context of Kerala. The narratives on migration present the migrant community as a "modern" community. As the protagonist in one of the migrant novels Churam recalls, they are viewed as the "carriers of modernity" who envisage a modern society in Malabar. Since the time of this migration was particular for its implications in the nationalist modernization project, migrant community's engagement with modernity has to be analyzed in the context of the "nationalmodern" as proposed and promoted by the Indian nationalist movement. The Indian modernity, as commonly understood, is not simply an imitation of Western modernity, but it constantly "traditionalizes" itself in order to remain 'Indian'.

Migration introduced Malabar to a new peasant culture, value system and new ways of being. Seemingly, migration from the princely state of Travancore to British Malabar resulted in the exclusion of those Syrian Christians from the mainstream discourse, which has its influences over the public and private spheres of the society. Here, it is relevant to look at the construct of the Syrian Christian identity in the public sphere of Kerala. They are seen as experts in the cultivation of cash crops; besides they are successful in trade and commerce. A significant observation on the farming culture of Kerala claims that food-grain and cash crop signify two different value systems in the cultural imaginations of Kerala (Madhusoodanan, 2006, P. 143). The point is that, the formation of the typical Syrian Christian identity can have two premises: it can be seen as the extension of the economic and social immobility in colonial Malabar and it is predicated on the value systems associated with the new peasant culture. The migrants imported and represented this different value system which is alien to the region. For instance, in the context, land is the site of the discourse of modernity and it has different significations in the life of Hindu and Christian religiosity. When land is portrayed as sacred in Hindu religious traditions, Christian religiosity does not accord any divine status to land. In certain interpretations of Biblical promises, land/earth is viewed as something that has to be subdued and dominated.

Through the introduction of the new peasant culture and the role of "carriers of modernity," the migrants become a part of the urbanization of the land and thereby became part of colonial ideology. In spite of this, they could not be a part of the nation since they possess an alternative national (religious) identity which leaves their spiritual domain empty in terms of "traditions." Thus, their identity was viewed as something antagonistic to the essential sense of nationalism as conceived by hegemonic Hinduism. While examining the issues pertaining to this peasant migration, it seems that the Christian subject had to constantly engage with the idea of nationalism by satisfying the spiritual domain through various means.

The narratives which contextualize migration include literary works like novels, souvenir books and commemorative volumes on special occasions by churches, and autobiographical works by religious leaders. The public sphere has always been a site where the privileged communities of the society establish and exercise their ideology and the mainstream literature has always represented this public sphere. The mainstream literary works on migration in Malayalam tend to valorize this spiritual domain in its discourse on nationalism. The migrants 
own understanding of the event is taken for granted in them whereas the not-so-popular migrant novels seem to offer a different, if not counter hegemonic discourse of migration. The major works in this category include Bespurkkana [2006], Mariyathinte Makkal [Children of Mariyam 2005], Churam [Mountain Pass, 1976], Chulli [Twig] [1977], Achamma [1968], and Dukhabhoomi [Bereaved Land, 1967]. Thikkodiyan's plays Kanakam Vilayunna Mannu [Gold Yielding Earth, 1986] and Kanyadanam [Virgin Gift, 1957] also focus on migrant life by portraying the ordeals of the migrant in a different land. They had to earn a new respectability in the land both as religious subject and a national subject; an ordeal which they eventually succeeds in.

Apparently, mainstream literature represents migrants as "others." And the existence of alternative narratives can be seen as a response to the way in which mainstream literature has demonized or simply erased the migrant experience in the land. Another reason why the novels were "invisible" in Malayalam mainstream literature owes to the politics of representation and language. They were not considered as "standard works" since they are thought to be inferior to those that come under the mainstream literature. As V. J. Varghese observes, these novels come under the category of "janapriya sahithyam" (popular fiction) in Malayalam literature because of the differences they show when compared to the so called "elitist" writings (Varghese, 2005, P. 328). This "janapriya sahithyam," i.e., popular literature is supposedly intended to titillate the imagination of the public. Moreover, these texts were not thought as having any importance in the cultural sphere. The classification or ranking of literary works into "elite" and "low" texts is part of the dominant discourse. Strikingly, Besppurkkana is the only novel which acknowledges the identity of the Adivasi communities of Malabar along with the story of migration. Their understanding of the event is often taken for granted in other novels. Hence, the very existence of this literature can be viewed as a contestation with the mainstream notion of the migrant self.

The image of the migrant as articulated in these mainstream novels is fabricated within a nexus of tensions created by colonial and nationalist contestations. This is at odds with the image of the migrant postulated by the novels like Vishakanyaka, which views migration as a kind of invasion into the social and cultural realms of Malabar. Hence,

"The literary representations of the migrants are political articulations necessitated by specific historical circumstances. The careful configuration of a migrant self by the "low" texts under discussion can be read as an intervention of the migrant imagination against a burgeoning sense of cynicism towards the very historical enterprise they were taking part in or were taking part of. (Varghese, 2005, P. 328)."

These political articulations seem to be conditioned by their religious identity and the emerging communal politics of the region. The migrants are considered more modernized than the natives of Malabar in view of the fact that migration resulted in the establishment of secular educational institutions all over Malabar. The novels also stage inter-religious marriages. For instance, the marriage of Vakkan and Unniperi was supported by a group of migrants who believe that opposition to inter-religious marriages is against the ideology of a "modern society" (Varkey, 1976). They got married without any religious or customary rites. The migrants were also anxious about the forthcoming Home Rule if the British goes away from the land. The obvious suggestion is that, for the migrants, colonial rule meant "Christian rule" while home rule meant "Hindu rule." The novel Dukhabhoomi is a long description of the socio-political tensions prevalent during the time of settlement. It also discusses the political polarization of Malabar through the perspective of the migrant. In general, the migrant narratives represent the migrant subject as a powerless opponent to the native elites. Hence, the "political necessity" seems to be a necessity to get their Christian migrant identity legitimized. Here, it is important to note that these novels represent 
the anticipation of a migrant Christian for entry into the political and social spheres of Kerala and, significantly, all of them were written after the formation of Kerala.

Community narratives offer another dimension to the discourse wherein many articles that appear in the souvenirs criticize this representation of migrant self in the mainstream narratives. A reading of the souvenirs and annual volumes published by churches and institutions related to them will help to understand the way in which Church negotiates with the secular state. The majority of them were published in the last thirty years. They have a general pattern and they share a common feature in the subject matter. Most of souvenirs and annual volumes publish articles on the history of the region and experiences of the migrants in the early years of the settlement. Memoirs by the migrant farmers themselves appear often in these texts. These memoirs give an account of the "heroic" participation of the migrants in the overall development of the region. All of them set apart pages to report the role of the Church in the construction of the "new" society in Malabar. The memoirs present the story of migration through a mixing of history and legend. Memoirs and autobiographies seem to possess journalistic authenticity since they are part of written history without, at the same time, negating the fact that these memoirs are a compound of allegory, legend and history.

The articles mainly deal with topics such as the role of women in a Christian family, the role of church in the society, etc. Exhortation for a morally correct life is the undercurrent of all the articles. The construct of the migrant self is conditioned by doctrinal Christianity with the concept of Holy family; and by the patriarchal notions of the identity of women within and their role outside the institution of family. Texts which I read alongside these memoirs are the autobiographies and biographical accounts of Christian religious leaders who were active in the establishment of the Church in Malabar. The autobiographies written by the priests, articulate a typical institutional and gendered religiosity while talking about the public/private dichotomy. It also has certain strategies to relate with the myth of nation making. It has certain methods to engage with the secular state. Here it is important to note that these publications are one of the modes of institutional communication within the community. Bishop Sebastian Valloppilly is a prominent figure among them. He was the foremost Bishop of the Diocese of Thalassery, the first Diocese of Malabar whose biography traces the story of migration along the lines of the establishment and dissemination of the Catholic Church in Malabar. Similar to the nature of souvenirs, his illustration of the migration story is firmly on the basis of Christian morality. The obvious culmination of the attempts to find the moral-migrant self is elucidated through a patriarchal discourse on femininity. The narrative specifies the inner and outer phases of the migrant life by dividing it into the public/private which is transformed as the masculine/feminine roles in the process of modernization. This gendered manifestation of inscribing a migrant self is common in all narratives produced on migration. Hence the narratives establish the migrant self as essentially male. Through a legendary detailing of the history of migration, the migrant male becomes a modern hero. Hence the narratives on migration write the female subject in accordance with the imagination of the project of anti-colonial nationalism.

Apart from the indirect representation of the "national," there are direct expressions to relate to the images of "nation." For example, one of the articles is entitled, "Manda Budhikalaaya Kuttikal Swayam Paryapthathayil Ethicherunnathinu Charkkayude Panku" [The Role of the Charkka in Making the Mentally Retarded Children Self Sufficient]. ${ }^{3}$ This deliberate attempt to relate themselves and their institutions' ideology to Gandhi seems to be an undertaking to relate Christianity to nationalism. Bishop Valloppilly remembers that there was a practice of choosing a motto when a Bishop takes over the control of the Diocese. His motto was "Profide et Patria" 
which means "for faith and for the nation" (Valloppilly, 1999, P. 399). The national flag was a part of his official emblem. Besides, he issued a circular ordering to set the national flag along with the papal flag on both sides of the "altar" in all the churches of Thalassery Diocese. These souvenirs published by the church are meant to be circulated only within the parish. They are addressed to a particular community which engages with the two spheres of colonial modernity. The first is the religious identity which was tied up with an imagined patronage of/ by imperial power. The second is the post-colonial state which sanctions a hegemonic nationalism. What is striking here is that there is a subtle ease with which metaphors come "naturally" in the mainstream narratives, while in migrant writings it is deliberate. Suggestively, this deliberate, categorical and often strategic use of the discourses of Indian modernity is part of Syrian Christian assertive religious identity which strives to claim legitimacy within and without. In a nutshell, the existence of the "minor" voices implies that it is the public sphere which denies a religious Christian that produces this kind of narratives. Thus, the "other" literature and subject here signifies the deviant and the subversive.

\section{Conclusion}

This reading of migrant narratives and minority experience along the lines of the currents of nation-making extends to the contemporary cultural and political milieu of Kerala/India where there is a subtle "fear" in the air about minority populations becoming stronger and articulate, particularly through various media. In such a scenario, it is very crucial that we investigate the nature of the dialogue between a so-called elite minority and Hindu nationalism. In my reading of the narratives pertaining to Malabar migration, I try to analyze the ways in which the Syrian Christian community negotiates the idea of a nation against the backdrop of migration. The Syrian Christian communitarian identity presents a curious case of being different by being the same, or being the same with a difference. Syrian Christian identity formation could be further examined by a reading of other texts and documents relating to their socio-political, cultural and religious history. I have chosen a narrower focus because migration is a significant event that impacted their identity-community whereby they were forced into dialogue with other communities within and outside the fold of Christianity and with an emerging religious nationalism. The narratives pertaining to Malabar migration is an important landmark in defining their community-identity in the colonial and post-colonial contexts.

\footnotetext{
Notes of Kerala.

${ }^{\text {ii }}$ A Hindu upper caste community in India.

iii Ashanilayam Inaguration Souvenir.
}

${ }^{\mathrm{i}}$ Travancore was a kingdom in South Indian which became a princely state under British India and it form the southern region of Kerala. Malabar constitute present day north Kerala and it was part of Madras presidency of British India. Malayalam was the common language spoken and according to the linguistic reorganization after independence, the two regions were unified along with Kochi to form the Indian state 


\section{References}

Abbas, R. (2016). Internal migration and citizenship in India, Journal of Ethnic and Migration Studies. 42(1) 150-168. DOI: 10.1080/1369183X.2015.1100067

Ali, A. (2001). Evolution of the Public Sphere in India, EPW. (36)26, 2419-2425. Retrieved from http://www.jstor.org

Alphonsa Namakarana Smaranika. (1986). Bharanaganam: Mar Thomas Moothedam Publishers.

Ashanilayam Inaguration Souvenir. (1994). Thalassery : Archdiocesan Archives.

Baby, K. J. (2007). Besppurkkana. Kottayam: DC Books.

Corn, D. A. (2000). Exodus Within Borders: An Introduction to the Crisis of Internal Displacement. Washington DC: Brookings Institution Press.

Chatterjee, P. (1993). The Nation and its Fragments: Colonial and Postcolonial Histories. New Delhi: Oxford University Press.

Daivam Nammodukude [God Is With Us]. (1999) Thalassery: Bishop Mar Sebastian Vallopilly.

Frykenberg, R. E. (2003). Introduction: Dealing with Contested Definitions and Controversial Perspectives. In R. E. Frykenberg, A. M. Low. (Eds.), Christians and Missionaries in India (pp. 1-32). Michigan: William. B. Eerdmans Publishing Company.

Gardner, K. and F. Osella. (2004). Migration, Modernity and Social Transformation in South Asia. New Delhi: Sage Publication.

Joseph, K. (1967). Dukha Bhoomi [Bereaved Land]. Champakulam: BKM Book Depot,

Joseph, K. (1968). Achamma. Champakulam: BKM Book depot.

Joseph, K. (1977). Chulli [Twig] Ernakulam: Prathiba Publications.

Joseph, K. (1991). Konippadikal [Stairs]. Calicut: Bobby Books.

Joseph, K. V. (2005). Socio-Cultural Determinants and the Peasant Migration from Travancore to Malabar. In K. S Mathew, M. Singh and J. Varkey. (Eds.), Migration in South India (pp. 108-137). New Delhi: Shipra Publications.

Kakkanadan, G. V. (2002). Orotha. Kollam: Sankeerthanam Publications.

Kaviraj, S. (2003). A State of Contradictions: the Post-Colonial State in India. In Queitin Skinner and Bo Strath. (Ed.). State and Citizens: History, Theory, Prospects (pp. 145-163). New Delhi: Cambridge University Press.

Korn, D. A. (2000). Exodus within Borders. Washington DC: Brookings Institution Press.

Longkumer, A. (2017) The power of persuasion: Hindutva, Christianity, and the discourse of religion and culture in Northeast India. Religion. 47(2), 203-227.

Madhusoodanan, G. (2006). Kathayum Paristhithiyum [Environment and the Story]. Kottayam: Current Books.

Mallampally, C. (2004). Christians and Public Life in Colonial South India; 1863-1937. New Delhi: Orient Longman.

Mattom, J. (1964). Karutha Ponnu [Black Gold]. Manathody: St. Joseph’s Press.

Menon, D. M. (2002). Religion and Colonial Modernity, EPW. 37(17) 1662-1667. Retrieved from http://www.jstor.org

Metropolitan's Silver Jubilee Souvenir: Malabar Diocese. (1991). Kozhikode: Diocese of Malabar.

Mishra, D. K. (Ed.). (2016). Internal Migration in Contemporary India. New Delhi: Sage Publications.

Pandian, M. S. S. (2003). Nation as Nostalgia: Ambiguous Spiritual Journeys of Vengal Chakkarai, $E P W 38$ (51-52), 5357-5365. Retrieved from http://www.jstor.org

Ponnattu, A. (Ed.). (2005). Kudiyettathinte Ithihasam: Athiroopatha Charithra Smrithikal. [Saga of Migration: Historical Memoirs of Archdioces]. Thalassery: Golden Jubilee Documentation Committee.

Pottekkatt, S. K. (2006). Vishakanyka [Poisonous Virgin]. Kottayam: D.C.Books.

Skaria, Z. (2000). Kudiyettavum Pravaasavum Malayala Sahithyathil ["Migration and Exile in Malayalam Literature"]. In Vijayan, M. N. (Ed.), Nammude Sahithyam Nammude Samooham [Our Literature, Our Society] (pp. 295-312). Thrissur: Kerala Sahithya Academy.

Sreekumaran Nair, M. P. (1981) Kerala Christians and Indian National Movement: An Overview. In John, K. J. (Ed.), Christian Heritage of Kerala (pp. 284-289). Cochin: Published by Fr. George Velliparambil.

Studdert-Kennedy, G. (1991). British Christians, Indian Nationalists and the Raj. New Delhi: Oxford University Press,. 
Studdert-Kennedy, G. (2002). Theology and Authenticity, Constitution and Improvisation: the Colonial Church in India. In J. M. Brown and R. E. Frykenberg. (Eds.), Christians, Cultural Interactions and India's Religious Tradition (pp. 154-182). Michigan: Wm. B. Eerdmans Publishing Co.

The 8oth Birth Centenary Celebration of St. Anthony Souvenir. (1996). Olloor: St. Anthony's Forona Church.

Thikkodiyan. (1957). Kanyadanam [Virgin Gift]. Kozhikode: Kerala Book Depot.

Thikkodiyan. (1986). Kanakam Vilayunnna Mannu [Gold Yielding Earth]. In Thikkodiyante Thiranjadutta Nadakangal. Calicut: Mathrbhoomi Printing and Publishing Company. 169-255.

Valavoor, Z. (1995). Malabarinoru Mosses. [A Mosses for Malabar]. Kottayam: Zacharias Valavoor.

Varghese, V. J. (2006). Migrant Narratives: Reading Literary Representations of Christian Migration in Kerala, 1920-1970, Indian Economic and Social History Review. 43(2), 227-255.

Varghese, V. J. (2005). De-scribing Self: Reading Migrant Novels on Malabar Migration, Thapasam: A Journal of Kerala Studies, 1(2), 326-348.

Varkey, P. T. (2005). Mariyathinte Makkal [Children of Mariyam]. Aluva: Pen Books.

Varkey, T. (1976). Churam [Mountain Pass]. Mananthody: St. Thomas Press.

Visvanathan, S. (1993). Christians of Kerala: History, Belief and Ritual among the Yakoba. Madras: Oxford University Press.

Viswanathan, G. (1998). Outside the Fold: Conversion, Modernity and Belief. New Delhi: Oxford University Press.

Williams, R. B. (2000). South Asian Christians in Bratain, Canada and the United States. In Harold Coward et al. (Eds.). The South Asian Religious Diaspora in Britain, Canada and the United States. (pp. 13-32). Albany: State University of New York.

Zacharia, K. C., E. T. Mathew and S. Irudayarajan. (2003). Dynamics of Migration in Kerala: Dimensions, Differentials and Consequences. New Delhi: Orient Longman.

Ambili Anna Markose is pursuing research at the Centre for Comparative Literature, University of Hyderabad. Her doctoral research is on Visual Culture Practices and Minorities in Kerala. Her research interests include minority discourse, religious studies and Malayalam literature. 